\title{
Neuronal Expression of Glypican, a Cell-Surface Glycosylphosphatidylinositol-anchored Heparan Sulfate Proteoglycan, in the Adult Rat Nervous System
}

\author{
E. David Litwack, ${ }^{1}$ Christopher S. Stipp, ${ }^{1}$ Asli Kumbasar, ${ }^{1}$ and Arthur D. Lander ${ }^{1,2}$ \\ 'Department of Biology and 'Department of Brain and Cognitive Science, Massachusetts Institute of Technology, \\ Cambridge, Massachusetts 02139
}

Cell-surface proteoglycans have been implicated in cell responses to growth factors, extracellular matrix, and cell adhesion molecules. M12, one of the most abundant membrane-associated proteoglycans in the adult rat brain, is a 〜65 kDa glycosylphosphatidylinositol-linked protein that bears heparan sulfate chains (Herndon and Lander, 1990). To assess its identity, M12 was purified and internal peptide sequences obtained. Comparison of the results with protein sequence predicted by a cDNA cloned from PC12 cells indicated that $M 12$ is rat glypican, a proteoglycan first cloned from human fibroblasts. In addition, antibodies raised against a rat glypican fusion protein specifically detected the $65 \mathrm{kDa}$ brain proteoglycan core protein, both by immunoprecipitation and by Western blotting. Northern blot analysis using a rat glypican probe also detected glypican message in the adult, as well as the developing rat brain.

In situ hybridization with glypican RNA probes showed that glypican is expressed in a subset of structures in the adult rat nervous system. These include the hippocampus, dorsal thalamus, amygdala, cerebral cortex, piriform cortex, olfactory tubercle, several cranial nerve nuclei, the ventral horn of the spinal cord, and the dorsal root ganglia. Several other brain regions exhibited little or no hybridization over background. In most cases where glypican hybridization was observed, the signal could be localized specifically to the cell bodies of identifiable neurons, for example, spinal motoneurons, hippocampal pyramidal cells. In the cerebral cortex, glypican hybridization was found in layers $2 / 3,5$, and 6 , but was missing from 1 and 4 . The data suggest that glypican is expressed primarily by subpopulations of projection neurons in the adult rat nervous system.

IKey words: glypican, glycosylphosphatidylinositol, heparan sulfate proteoglycan, in situ hybridization, $m R N A$, neurons]

The interaction of cells with their environment is important for the growth and function of the nervous system. These interactions control processes such as cell adhesion, migration, prolif-

\footnotetext{
Reccived Junc 29, 1993; reviscd Scpt. 28, 1993; accepted Nov. 24, 1993.

We thank Rosario Moratella, Sonal Jhaveri, Clive Wilson, and Jerry Yin for technical advice, Todd Grinnell for technical assistance, John Wagner for the gift of the A 126 cDNA library, and Ann Graybiel, Jonathdn Ivins, and Mary Herndon for helpful comments on the manuscript. This work was supported by NIH Grant NS26862.

Correspondence should be addressed to E. David Litwack, E25-417, M.I.T. Cambridge, MA 02139.

Copyright (C) 1994 Society for Neuroscience $0270-6474 / 94 / 143713-12 \$ 05.00 / 0$
}

eration, axon growth and guidance, and responsiveness to growth factors. Proteoglycans (PGs), proteins that contain one or more covalently attached glycosaminoglycan (GAG) chains, are thought to be involved in many such interactions. PGs are found both in the extracellular matrix and on cell surfaces. Through their GAG chains PGs have the ability to bind a number of important nervous system proteins, including extracellular matrix proteins (such as laminin, fibronectin, thrombospondin, and agrin), cell-surface molecules (such as NCAM, myelin-associated glycoprotein, the amyloid- $\beta$-protein precursor), synaptic cnzymcs (AChE) and growth factors of the fibroblast growth factor (FGF) family (for reviews, see Jackson et al., 1991; Lander and Calof, 1993). In some cases it has been demonstrated that GAGs - in particular, GAGs of the heparan sulfate (HS) classplay an essential role in the functions of these proteins. For example, cell-surface $\mathrm{HS}$ is apparently required for basic FGF (bFGF) to bind to cells and exert its effects (Rapraeger et al., 1991; Yayon et al., 1991; Kan et al., 1993), as well as for NCAMmediated cell adhesion (Cole et al., 1986; Reyes et al., 1990), and agrin-mediated clustering of muscle $\mathrm{ACh}$ receptors (Gordon et al., 1993).

Currently, it is not known which PGs in the nervous system mediate these and other biological activities, or where such PGs are expressed. Up to $25 \mathrm{PG}$ core proteins have been reported in the developing and adult rat brain (Herndon and Lander, 1990), including molecules bearing both HS and chondroitin sulfate (CS) GAGs. Those PGs for which information exists on regional distribution in the nervous system are mainly CSPGs; these include the Cat-301 antigen (Hockfield et al., 1990), neurocan (Rauch et al., 1992), versican (Perides et al., 1992), and the T1 antigen (Iwata and Carlson, 1993)-all of which appear to be extracellular matrix-associated-and one cell surface CSPG, NG2 (Stallcup et al., 1983; Levine and Card, 1987; Nishiyama et al., 1991). In addition, inmunological studies have identified distinct CS epitopes on subsets of CNS neurons (Fujita et al., 1989; Watanabe et al., 1989; Maeda et al., 1992).

In contrast, much less is known about the expression of PGs in the brain that bear HS chains. One, known as N-syndecan or syndecan-3 (for nomenclature, see Bernfield et al., 1992), is an integral membrane PG expressed mainly during perinatal development, and appears to be associated with many cell bodies (Carey et al., 1992). Other brain HSPGs have been characterized biochemically, but their distributions have not bccn elucidated (Margolis et al., 1975a,b; Klinger et al., 1985; Herndon and Lander, 1.990; Nurcombe et al., 1993).

Two of the major HSPGs of the rat brain, known as M12 and M13 (Herndon and Lander, 1990), associate with isolated mem- 
branes and exhibit detergent-partitioning properties indicative of integral membrane proteins. These PGs lose their detergentpartitioning properties.when treated with phosphoinositide-specific phospholipase $\mathrm{C}$, indicating that they associate with membranes via a covalent glycosylphosphatidyl-inositol (GPI) lipid linkage (Herndon and Lander, 1990). Several other HSPGs have been reported to possess GPI anchors, including HSPGs isolated from rat ovarian granulosa cells (Yanagashita and McQuillan, 1989), mouse melanoma cells (Drake et al., 1992), rat Schwann cells (Carey and Stahl, 1990), and human lung fibroblasts (David et al., 1990). The latter molecule was cloned and given the name glypican (David et al, 1990).

In the present study we describe the purification and cDNA cloning of M12 from rat brain and show that it is the rat homolog of glypican. In situ hybridization studies are presented that indicate that M12/glypican is regionally expressed in the adult brain. Specifically, glypican is found to be expressed at high levels by restricted populations of projection neurons.

Some of these data have been presented previously in abstract form (Litwack and Lander, 1992).

\section{Materials and Methods}

Purification of HSPG M12. A membrane fraction was isolated from $46.4 \mathrm{gm}$ wet weight of neonatal rat brains (roughly 165 animals), and a detergent extract of this fraction was prepared (Herndon and Lander, 1990). All further steps were done at $4^{\circ} \mathrm{C}$ except where noted. PGs were purified by loading the detergent extract onto a column $(172 \mathrm{ml})$ of DEAE-Sephacel, washing sequentially in $50 \mathrm{~mm}$ Tris- $\mathrm{HCl}(\mathrm{pH} 8.0$ at $\left.4^{\circ} \mathrm{C}\right), 0.1 \%$ Triton X-100, and protcase inhibitors as in Herndon and Lander (1990) containing (1) $0.15 \mathrm{M} \mathrm{NaCl}$ (starting buffer), (2) $0.25 \mathrm{M}$ $\mathrm{NaCl}$, (3) $0.25 \mathrm{M} \mathrm{NaCl}, 6 \mathrm{~m}$ urea, and (4) $0.25 \mathrm{M} \mathrm{NaCl}, 6 \mathrm{M}$ urea, with $50 \mathrm{~mm}$ formate $(\mathrm{pH} \mathrm{3.5)}$ replacing the Tris- $\mathrm{HCl}$. The $\mathrm{pH}$ of the column was then restored to $\mathrm{pH} 8.0$ with starting buffer, and the PGs were eluted with starting buffer containing $0.75 \mathrm{M} \mathrm{NaCl}$. This PG-enriched fraction was concentrated and exchanged into starting buffer containing $0.15 \mathrm{M}$ $\mathrm{NaCl}$ using a Centriprep-10 (Amicon), and was then digested with 0.09 $\mathrm{U} / \mathrm{ml}$ chondroitinase $\mathrm{ABC}$ (Sigma) for $2 \mathrm{hr}$ at $37^{\circ} \mathrm{C}$. This material was loaded on a $0.2 \mathrm{ml}$ DEAE-Sephacel column, washed with starting buffer (without protease inhibitors) and then $0.2 \mathrm{M} \mathrm{NaCl}, 6 \mathrm{M}$ urea, $100 \mathrm{~mm}$ sodium acetate $(\mathrm{pH} 3.5), 0.1 \%$ Triton $\mathrm{X}-100$. The column was washed with $25 \mathrm{~mm}$ ammonium acetate $(\mathrm{pH} 7.0), 0.1 \%$ Triton $\mathrm{X}-100$ and eluted with a $20 \mathrm{ml} 0.15 \mathrm{M}-0.75 \mathrm{M} \mathrm{NaCl}$ gradient in this buffer. The fractions from $0.3 \mathrm{M}$ to $0.75 \mathrm{M} \mathrm{NaCl}$ werc pooled, and this PG-enriched fraction, now depleted of CSPGs, was concentrated and exchanged into $25 \mathrm{~mm}$ ammonium acetate $(\mathrm{pH} 7.0), 0.1 \%$ Triton $\mathrm{X}-100,0.15 \mathrm{M} \mathrm{NaCl}$ in a Centricon-10. This sample was made $25 \mathrm{~mm}$ in Tris- $\mathrm{HCl}(\mathrm{pH} 7.1$ at $37^{\circ} \mathrm{C}$ ) and digested with $9 \mu \mathrm{g} / \mathrm{ml}$ heparitinase (prepared as in Herndon and Lander, 1990) for $3 \mathrm{hr}$ at $37^{\circ} \mathrm{C}$. The sample was concentrated in a Centricon-10, subjected to electrophoresis in a 9\% SDS-PAGE gel (Lae$\mathrm{mmli}, 1970$ ), and electroblotted to nitrocellulose (Schleicher and Schuell). HSPG core proteins were visualized by amido black staining (Schaffner and Weissman, 1973). M12 and M13 were excised, and were simultaneously eluted from the filters and digested with trypsin as in Tempst et al (1990). The tryptic peptides were separated by reverse-phase HPLC. (Tempst et al., 1990) and microsequenced by automated Edman degradation (Biopolymers Lab, MIT).

Cloning and sequencing of rat glypican. To obtain a human glypican probe, cDNA was synthesized from $0.5 \mu \mathrm{g}$ of human foreskin fibroblast total RNA (purified as described by Chomczynski and Sacchi, 1987) using MMLV-reverse transcriptase (GIBCO-Bethesda Research Labs). This cDNA was then amplified by PCR using 120 pmol each of oligonucleotides GLA (5'-ggtccggaaagtggctcaggtc- $\left.3^{\prime}\right)$ and GLB (5'ggttgttgatctggttggccag- $\left.3^{\prime}\right)$. These primers correspond respectively to bases 920-941 (in the sense orientation) and 1539-1518 (in the antisense orientation) of human glypican (David et al., 1990). PCR was performed for 30 cycles: $94^{\circ} \mathrm{C}$ for $30 \mathrm{sec}, 55^{\circ} \mathrm{C}$ for $1 \mathrm{~min}$, and $72^{\circ} \mathrm{C}$ for $1.5 \mathrm{~min}$. The resulting product was digested with Xhol and Kpn 1 (human glypican contains an Xhol site at base 690 and a Kpn 1 site at base 1494), isolated by agarose gel electrophoresis, and cloned into pBlucscript (Stratagene). The clone was verified by partial sequencing.
A Lambda-Gem 2 cDNA library (gift of Dr. John Wagner, Cornell University Medical School) constructed from A126 cells (a PC12 rat pheochromocytoma cell variant) was screened with the human glypican fragment labeled by the random primer method. Twelve positive clones were obtained from an initial screen of 400,000 plaques. The inserts from positive phage were subcloned into the EcoR 1 site of pBluescript and both strands of the largest, a $3 \mathrm{~kb}$ clone designated $4 \mathrm{la}$, were sequenced by the dideoxynucleotide method using Sequenase (U.S. Biochemicals) or the fmol DNA Sequencing System (Promega). Sequencing primers were synthesized based on internal sequence (Biopolymers Lab, MIT), or restriction fragments were subcloned into pBluescript and sequenced using $\mathrm{T} 3$ and $\mathrm{T} 7$ primers. Clone 41 a contains 3000 base pairs (bp) of the $3^{\prime}$ end of rat glypican.

In order to obtain the $5^{\prime}$ fragment of rat glypican, a primer-extended cDNA library was constructed from $5 \mu \mathrm{g}$ of PC12 polyA+ RNA using the Time-Saver kit (Pharmacia). This polyA+ RNA was isolated over oligo-dT cellulose using the FastTrack kit (Invitrogen). The oligonucleotide RG6 (5'-cctgcacaaaggatcgt- $3^{\prime}$, situated 213 bp downstream of the $5^{\prime}$ end of clone 41 a) was used to prime first-strand synthesis. The final cDNA product was ligated into the EcoR 1 site of pBluescript and transformcd into XL1-Bluc cclls. A clonc of about $950 \mathrm{bp}$, designatcd 7a3, was obtained by colony hybridization with probe 4EX (see below). Both strands of $7 \mathrm{a} 3$ were sequenced as above, and assembled with 41 a based on their overlapping sequence. The assembled cDNA contains an open reading frame that predicts the glypican amino acid sequence.

In order to obtain glypican cDNA fragments directly from rat brain, PCR was performed as above from $0.5 \mu \mathrm{g}$ of rat brain total RNA using the following sets of oligonucleotides: (1) RG15 (5'-tttgttgtctccgcctcctcg$3^{\prime}$ ) and RG12 (5'-acgtcgctcaggctaaag-3'), (2) RG11 (5'-cactgccgtcatcactgg- $\left.3^{\prime}\right)$ and RG10 (5'-tgctcaaaggctgccttg- $3^{\prime}$ ), (3) RG1 1 and RG4 (5'ctcatcactgacaagttc- $3^{\prime}$ ), and (4) RG5 (5'-aggatgccagtgatgacg- $3^{\prime}$ ) and RG7b ( $5^{\prime}$-tggccaagacagtccttt-3'). The PCR products were purified on a $2 \% \mathrm{Nu}$ sieve (FMC) agarose gel, and sequenced with Taq polymerase using the fmol sequencing kit (Promega), and oligonucleotides end-labeled with ?.P-ATP.

Rat glypican probes. Probe 4EX is a 162 bp EcoR 1 -Xhol fragment from clone $41 \mathrm{a}$ inserted into pBluescript. Antisense RNA probes were made by digesting the plasmid with EcoR 1 and transcribing with $\mathrm{T} 7$ RNA polymerase (Stratagene) in the presence of ${ }^{35} \mathrm{~S}-\mathrm{UTP}$; sense RNA probes were synthesized by digesting with Xhol and transcribing with T3 RNA polymerase (Stratagene). Probe 4P1 is a 567 bp Pst 1 fragment subcloned from $41 \mathrm{a}$ into $\mathrm{pBluescript}$. Antisense RNA probes were made by digesting with EcoR 1 and transcribing with T7 RNA polymerase. Probe 4P2 is a 332 bp Pst 1 fragment subcloned from 41a into pBluescript. Antisense RNA probes were made by digesting with $\mathrm{BamH} 1$ and transcribing with T7 RNA polymerase. A rat glyceraldehyde phosphate dehydrogenase DNA probe was a gift of Dr. Timothy Hayes (NIH). Probes for Northern blots were labeled with ${ }^{32} \mathrm{P}$-dCTP using the Random Primer Labcling Kit (U.S. Biochemicals), and denatured at $100^{\circ} \mathrm{C}$ for $7 \mathrm{~min}$ before use.

Northern blotting. Total RNA, purified as described by Chomczynski and Sacchi (1987), was separated by electrophoresis in a $1.2 \%$ agarose/ $6.4 \%$ formaldehyde gel and transferred to nitrocellulose by capillary blotting. The filter was air dried for at least $1 \mathrm{hr}$, and then vacuum baked for $2 \mathrm{hr}$ at $80^{\circ} \mathrm{C}$. Prehybridization was carried out at $42^{\circ} \mathrm{C}$ overnight in $50 \%$ formamide, $5 \times$ saline-sodium phosphate-EDTA (SSPE), $5 \times$ Denhardt's, $0.1 \%$ SDS, $0.2 \mathrm{mg} / \mathrm{ml}$ yeast RNA, and $0.1 \mathrm{mg} / \mathrm{ml} \mathrm{salm}$ on sperm DNA. Hybridization was carried out at $42^{\circ} \mathrm{C}$ for $2 \mathrm{~d}$ in $50 \%$ formamide, $5 \times$ SSPE, $1 \times$ Denhardt's, $0.1 \%$ SDS, and $0.1 \mathrm{mg} / \mathrm{ml}$ yeast RNA. Filters were washed once at $42{ }^{\circ} \mathrm{C}$ in $50 \%$ formamide, $5 \times$ SSPF, $0.5 \%$ SDS for $30 \mathrm{~min}$, twice at $42^{\circ} \mathrm{C}$ in $1 \times \mathrm{SSPE}, 0.5 \% \mathrm{SDS}$ for $15 \mathrm{~min}$ each, and twice at $65^{\circ} \mathrm{C}$ in $0.1 \times \mathrm{SSPE}, 0.5 \% \mathrm{SDS}$ for $30 \mathrm{~min}$ each. Filters were exposed to Kodak $\mathrm{X} \Lambda \mathrm{R}-5$ film at $-80^{\circ} \mathrm{C}$ and/or imaged using a phosphorimager (Molecular Dynamics, Sunnyvale, CA).

In situ hybridization. Brains from 6-7-week-old female Sprague-Dawley rats were dissected and quick frozen in isopentane chilled on dry ice. Cryostat sections $(10 \mu \mathrm{m})$ were thawed onto gelatin-coated slides or Probe-On Plus slides (Fisher). Sections were stored at $-80^{\circ} \mathrm{C}$ until use.

In situ hybridization was performed as described by Simmons et al. (1989). Briefly, sections were pretreated by fixation with $4 \%$ paraformaldehyde in PBS for $5 \mathrm{~min}$, washed in $2 \times$ saline-sodium citrate (SSC), and treated with acetic anhydride to block positive charges. Sections were then washed again in $2 \times$ SSC, dehydrated stepwise in ascending alcohol concentrations, delipidated (in some instances) in chloroform for $10 \mathrm{~min}$, washed again in 100\% ethanol, and dried for at least $1 \mathrm{hr}$. 


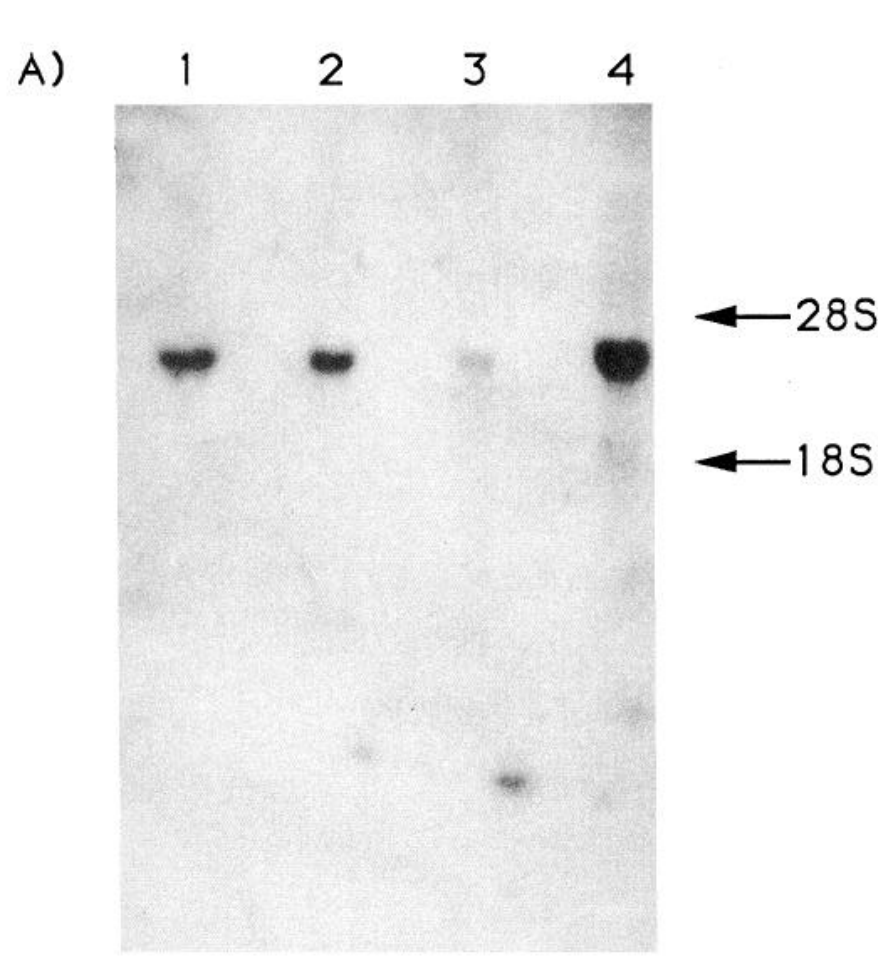

B)
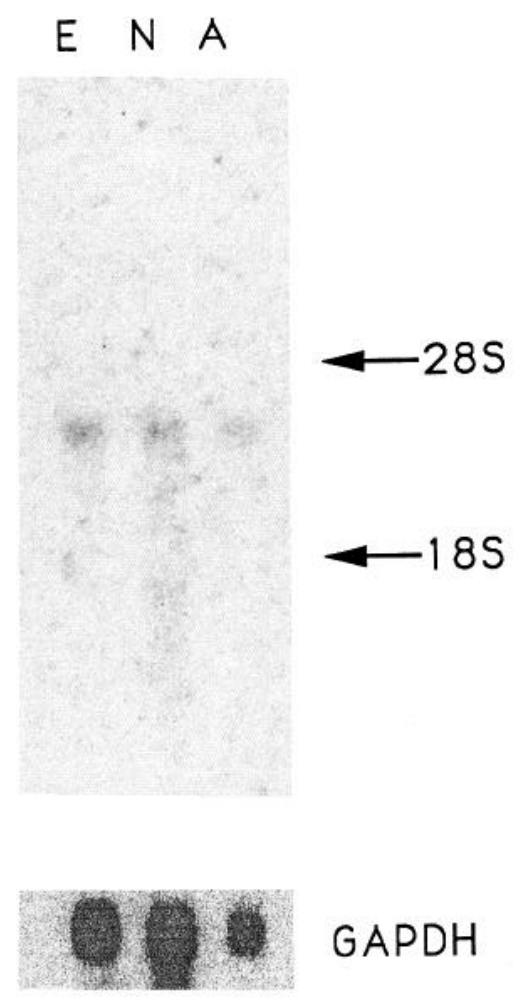

GAPDH

Figure 1. Detection of glypican message in rat brain, PC12 cells, and fibroblasts. $A$, Northern blot of $30 \mu \mathrm{g}$ of total RNA probed with a human glypican cDNA. Lane 1, Rat fibroblast cell line F2408 RNA; lane 2, PC12 cell RNA; lane 3, neonatal rat brain RNA; lane 4, human foreskin fibroblast RNA. $B$, Northern blot of $20 \mu \mathrm{g}$ of total RNA from rat brain probed with rat glypican cDNA probe 4 X1. Lane $E$, embryonic day 18 rat brain RNA; lane $N$, neonatal rat brain RNA; lane $A$, adult rat brain RNA. The filter was stripped and reprobed for rat glyceraldehyde phosphate dehydrogenase (shown below), to demonstrate the efficiency of loading and transfer of RNA. Levels of glypican RNA relative to this control RNA are roughly equivalent at the three developmental stages. Arrows in $A$ and $B$ point to position of $18 \mathrm{~S}$ and $28 \mathrm{~S}$ ribosomal RNA bands.

Sections were incubated overnight at $55-60^{\circ} \mathrm{C}$ in $50 \%$ formamide, $10 \%$ dextran sulfate, $0.3 \mathrm{~m} \mathrm{NaCl}, 1 \times$ Denhardt's solution, $1 \mathrm{~mm}$ EDTA, $10 \mathrm{~mm}$ Tris (pH 8.0), $0.1 \mathrm{mg} / \mathrm{ml}$ yeast tRNA, $200 \mathrm{~mm}$ DTT, $1 \%$ sarcosyl, and RNA probes at a concentration of $5 \times 10^{6}$ to $1 \times 10^{7} \mathrm{cpm} / \mathrm{ml}$.

Sections were washed several times in $4 \times$ SSC, treated with RNase A for 30-60 min, washed in descending salt concentrations, and incubated in $0.1 \times \mathrm{SSC}$ at $60^{\circ} \mathrm{C}$ for $30 \mathrm{~min}$. Sections were then dehydrated in ethanol and dried. Sections were exposed to Hyperfilm- $\beta$ Max (Amersham) or XAR-5 film (Kodak) for $10-14 \mathrm{~d}$ at $-80^{\circ} \mathrm{C}$. Sections were dipped in NTB-2 diluted $1: 1$ in water, stored at $-80^{\circ} \mathrm{C}$ for $15-30 \mathrm{~d}$, developed in D-19 (Kodak), counterstained with either cresyl violet or bisbenzimide (Hoechst 33258; Sigma), and studied with dark-field optics on a Zeiss Axiophot or WILD microscope. Hybridized sections were compared in some cases with nearby sections stained with cresyl violet, and with sections illustrated by Paxinos and Watson (1986) and Swanson (1992).

Production of glypican polyclonal antibodies. The EcoR 1 fragment of glypican clone 4la was cloned into the EcoR1 site of pMalc2 (New England Biolabs), producing a construct that encoded a fusion protein of glypican with the bacterial maltose-binding protein. The construct was sequenced to verify that the junction was in-frame. The fusion protein was induced by IPTG, and isolated by affinity chromatography on an amylose column (New England Biolabs). The fusion protein was then dialyzed into $150 \mathrm{~mm} \mathrm{NaCl}, 20 \mathrm{~mm}$ Tris- $\mathrm{HCl}(\mathrm{pH} 7.5), 25 \mathrm{~mm}$ octyl- $\beta$-D-glucopyranoside. Antibodies were raised at Pine Acre Rabbitry and Farms (Norton, MA). Rabbits were injected intradermally with $0.5 \mathrm{mg}$ of fusion protein in complete Freund's adjuvant and boosted subcutaneously with $0.5 \mathrm{mg}$ of fusion protein in incomplete Freund's adjuvant. After two boosts, sera were collected and antibodies were purified over fusion protein coupled to Affi-Gel 10 (Bio-Rad).

Immunoprecipitation. Embryonic day 18 and adult rat brain membrane PGs were prepared and radioiodinated as described by Herndon and Lander (1990) and boiled in 0.1\% SDS to disrupt aggregates of PGs that are present (cf. Herndon and Lander, 1990),; Triton X-100 was then added to a final concentration of $1 \%$. This material was incubated overnight at $4^{\circ} \mathrm{C}$ with $5 \mu \mathrm{g}$ of affinity-purified anti-glypican antibodies, and then absorbed to protein A-Sepharose (Sigma) for $1 \mathrm{hr}$ at $4^{\circ} \mathrm{C}$. The protein A-Sepharose was then washed sequentially in $0.1 \mathrm{~m}$ Tris $(\mathrm{pH}$ 7.5), 2 тм EDTA, 0.5\% 3-[(3-cholamidopropyl)dimethylammonio-]1-propanesulfate (CHAPS) containing (1) $150 \mathrm{~mm} \mathrm{NaCl}$, (2) $0.5 \mathrm{M} \mathrm{NaCl}$, and (3) $150 \mathrm{~mm} \mathrm{NaCl}$; each wash was done at $4^{\circ} \mathrm{C}$ for $30 \mathrm{~min}$. Antibodyantigen complexes were dissociated by boiling the Sepharose in $0.5 \%$ SDS and diluting into $1 \%$ Triton X-100, 50 mм Tris, 15 mм phosphoric acid ( $\mathrm{pH} 7.3)$, and protease inhibitors. Aliquots were digested with heparitinase at a concentration of $2 \mu \mathrm{g} / \mathrm{ml}$ at $43^{\circ} \mathrm{C}$ for $3 \mathrm{hr}$. Undigested and heparitinase digested samples were separated by electrophoresis on

Table 1. Sequence of tryptic peptides of purified M12 compared with human glypican

\begin{tabular}{|c|c|}
\hline Peptide 15 & AEALRPFGDAPR \\
\hline Human glypican & $\begin{array}{l}|||||||||||| \mid \\
\text { AEALRPFGDAPR }\end{array}$ \\
\hline Peptide 29 & BXLPEVMGDGLANQGXNPEVD \\
\hline & |||||||||||||||| $\mid$ : \\
\hline Human glypican & RYLPEVMGDGLANQINNPEVE \\
\hline Peptide $15 \mathrm{a}$ & $\begin{array}{l}\text { MELETALHDSSR } \\
:||||||:||||\end{array}$ \\
\hline Human glypican & AELETALRDSSR \\
\hline Peptide 26 & $\begin{array}{l}\text { BALQATLATQLHGIDDHFQ } \\
|:||||||||::||||| \mid\end{array}$ \\
\hline Human glypican & RVLQAMLATQLRSFDDHFQ \\
\hline
\end{tabular}

Solid lines represent identities; dotted lines represent amino acids with similar properties. B refers to either $\mathrm{K}$ or $\mathrm{R}$. 
MELRARGWWLLCAAAALVACARGDPASKSRSCSEVRQIYGAKGFSLSDVPQAEISGEHLRI 61 (rat) CPQGYTCCTSEMEENLANHSRMELETALHDSSRALOATLATOLHGIDDHFORLLNDSERTL 122

QDAFPGAFGDLYTQNTRAFRDLYAELRLYYRGANLHLEETLAEFWARLLERLFKQLHPQLL 183

LPDDYLDCLGKQAEALRPFGDAPRELRLRATRAFVAARSFVQGLGVASDVVRKVAQVPLAP244

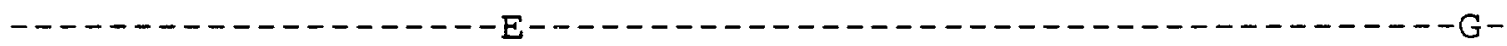

ECSRAVMKLVYCAHCRGVPGARPCPDYCRNVLKGCLANQADLDAEWRNLLDSMVLITDKFW305

- - - - - - - - - - - - L- - - - - - - - - - - - - - - - - - - - - - - - - - - - - - - - -

GPSGAENVIGSVHMWLAEAINALQDNKDTLTAKVIQGCGNPKVNPHGSGPEEKRRRGKLAL 366

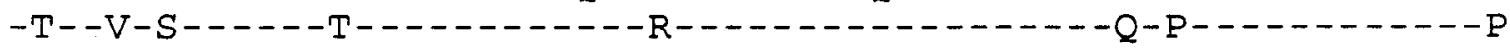

QEKSSTGTLEKLVSEAKAQLRDIQDYWISLPGTLCSEKMAMSPASDDRCWNGISKGRYLPE 427

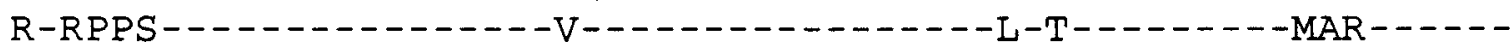

VMGDGLANOINNPEVEVDITKPDMTIRQQIMQLKIMTNRLRGAYGGNDVDFQDASDDGSGS 488

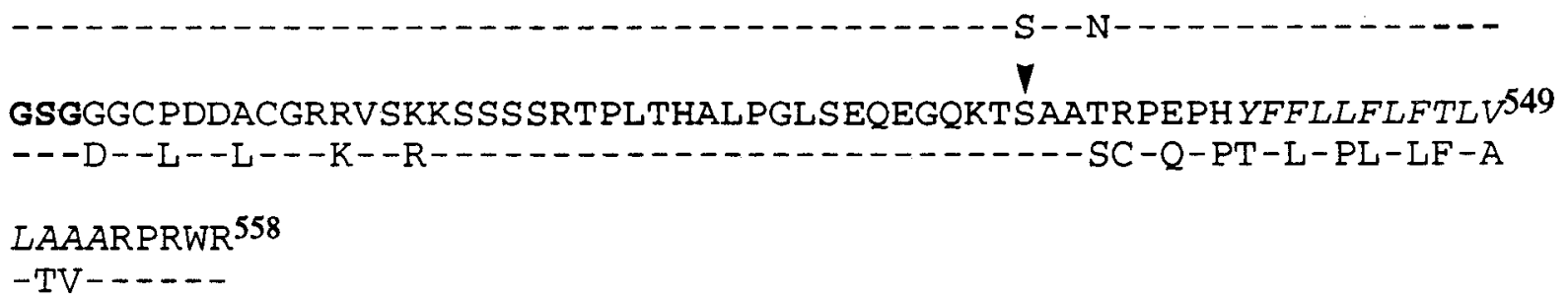

Figure 2. Comparison of rat and human glypican predicted protein sequences. The rat sequence is listed on top; the human, on the bottom. Amino acids in the human sequence identical to those in the rat sequence are indicated with a dash; differences are listed. Potential glycosaminoglycan attachment sites are indicated in boldface; potential $N$-linked glycosylation sites are indicated by asterisks; potential glypiation site is indicate by an arrow; putative $N$ - and $C$-terminal transmembrane hydrophobic stretches (corresponding respectively to putative signal and glypiation sequences) are indicated in italic; regions corresponding to microsequenced peptides derived from purified M12 are underlined. The nucleotide sequence of the full-length cDNA extends about $70 \mathrm{bp}$ past the $5^{\prime}$ end and 200 bases beyond the $3^{\prime}$ end of the cDNA reported by Karthikeyan et al. (1992). Sequence was assembled from clones $7 \mathrm{a} 3$ and $41 \mathrm{a}$. The $3^{\prime}$ end of clone $7 \mathrm{a} 3$ corresponds to base 883 and the $5^{\prime}$ end of $41 \mathrm{a}$ corresponds to base 681 of the sequence in Karthikeyan et al. (1992).

a 10\% SDS-PAGE gel. The gel was dried and exposed to Kodak XAR-5 film at $-80^{\circ} \mathrm{C}$.

\section{Results}

To determine the identities of two rat brain PGs that had previously been shown to contain GPI anchors, HSPGs M12 (core $\left.M_{r} \sim 65 \mathrm{kDa}\right)$ and $\mathrm{M} 13\left(M_{r} \sim 55 \mathrm{kDa}\right)$ (Herndon and Lander, 1990) were purified from neonatal rat brain, and peptides derived from the two core proteins were sequenced. Four M12derived peptides were obtained. These possessed a total of about $80 \%$ identity to regions of the human glypican protein (Table 1 ), suggesting that MI2 is rat glypican. M13 peptides were not highly similar to human glypican, and were used to isolate a cDNA clone encoding a novel PG corc protein (Stipp ct al., 1994).

To obtain a rat glypican cDNA clone with which to compare the M12 peptides, a human glypican probe was synthesized via PCR. This probe detected a single $3.7 \mathrm{~kb}$ message in neonatal rat brain total RNA (Fig. 1A). A message of the same size was detected in human foreskin fibroblast RNA (Fig. $1 A$ ), in agree- ment with the previously reported human glypican message size from human lung fibroblasts (David et al., 1990). A single message of this size was also detected in $\mathrm{PCl} 2$ cells, a rat pheochromocytoma cell line, and was more abundant in RNA from these cells than in RNA from neonatal rat brain (Fig. 1A). This finding is consistent with previous evidence that an M12-like proteoglycan is the major, if not only, heparan sulfate proteoglycan found in PC12 cells (Herndon et al., 1991).

A full-length rat glypican clone was obtained from PC1 2 cells as described in Materials and Methods. The cDNA sequence predicts a protein that is $89 \%$ identical to human glypican (the degree of identity increases to $91 \%$ if GPI-attachment sequences, which should not be present in the mature protein, are removed). The predicted protein sequence also contains sequences identical to those of the peptides derived from M12 (Fig. 2). Antibodies raised and purified against a fusion protein synthesized from part of this CDNA detected M12 in a Western blot of rat brain membranes (data not shown) and also immunoprecipitated M12 from crude mixtures of PGs obtained from both embryonic and adult rat brain (Fig. 3). Thus, we conclude that M12 is the rat form of glypican. 
While this work was in progress, peptide sequences from a rat brain HSPG that were closely related to human glypican were reported (Karthikeyan et al., 1992). This report also contained a sequence for a rat glypican cDNA that contains four amino acid differences (due to single base differences) from the sequence presented here (Fig. 2): $\mathrm{T}$ instead of $\mathrm{A}$ at position 21, $\mathrm{Y}$ instead of $\mathrm{N}$ at position 312, $\mathrm{A}$ instead of $\mathrm{G}$ at position 362, and $\mathrm{I}$ instead of $\mathrm{T}$ at position 515. To address whether these differences represent sequence polymorphisms between rat glypican from PC12 cells and glypican from Sprague-Dawley rats, we used PCR to obtain, from Sprague-Dawley rat brain RNA, cDNA fragments spanning the regions of sequence discrepancy. Sequenceable PCR products were obtained that span three of the four regions (positions 312,362 , and 515), and direct sequencing of these fragments gave results that agreed in all cases with the sequence reported here for PC12 cells (data not shown). Consequently, the data do not support the existence of glypican sequence polymorphisms.

A Northern blot using a probe from the rat glypican cDNA confirmed that a single $3.7 \mathrm{~kb}$ glypican message is present in total RNA from adult rat brain, and also detected a similarly sized message in the embryonic (day 18) and neonatal rat brain (Fig. 1B). This is in agreement with the expression of M12 protein, which was detected at each of these stages (Herndon and Lander, 1990).

In situ hybridization experiments were undertaken to identify the cell types that express glypican in the adult rat nervous system. High levels of glypican expression were detected in several structures in the adult rat brain. In the hippocampus, glypican was expressed in high levels in the pyramidal cell layer (Fig. 4A). Furthermore, the pyramidal cell layer in regions CA3 and CA4 expressed glypican mRNA at substantially higher levels than in regions CA1 and CA2. Some hybridization was also seen to the dentate gyrus, although at lower levels than in regions CA3 and CA4. High levels of expression were also found throughout the dorsal thalamus (Fig. $4 A-C$ ), including the ventrolateral, ventrobasal, mediodorsal, lateral geniculate, and medial geniculate nuclei, but expression was not seen in the medial and lateral habenula nor in the ventral thalamus (e.g., the reticular nucleus and zona incerta).

Strong hybridization was also seen to certain nuclei of the amygdala (Fig. $4 A, B$ ), notably the pyramidal layer of the nucleus of the lateral olfactory tract and the basolateral nucleus. Weaker hybridization was seen to the lateral and basomedial nuclei, but no hybridization to the anterior, medial, central, and cortical

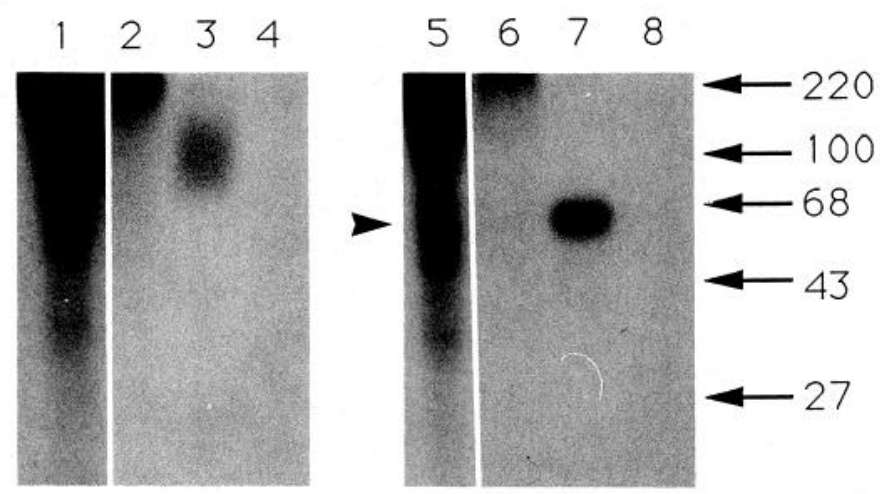

Figure 3. Antibodies raised against glypican fusion protein recognize adult rat brain HSPG M12. ${ }^{125}$ I-labeled adult rat brain PGs (Herndon and Lander, 1990) were immunoprecipitated with $5 \mu \mathrm{g}$ of rabbit IgG (lanes 2 and 6 ), $5 \mu \mathrm{g}$ of affinity-purified anti-glypican serum (lanes 3 and 7), or $5 \mu \mathrm{g}$ of anti-glypican serum containing $20 \mu \mathrm{g}$ of glypican fusion protein. Lanes 1 and 5 show the starting material. Samples were either subjected to SDS-PAGE without heparitinase treatment (lanes $1-4)$ or treated with heparitinase before electrophoresis (lanes 5-8). Arrowhead indicates the position of the M12 core protein. $M$, markers (in $\mathrm{kDa}$ ) are shown at right.

nuclei was detected. The sense strand of glypican did not hybridize to any of these or other structures (Fig. $4 D$ ). In addition, similar results were obtained using several antisense probes synthesized from different regions of glypican (see Materials and Methods) (data not shown).

Other forebrain structures tended to show somewhat less hybridization than that observed in the hippocampus, thalamus, and amygdala. These included the piriform cortex (Fig. $4 E$ ), olfactory tubercle (Fig. $4 E$ ), septal nuclei (data not shown), and the supraoptic (Fig. $4 B$ ) and paraventricular nuclei (data not shown) of the hypothalamus. Still weaker, but detectable hybridization was seen to the cerebral neocortex (Fig. $4 E$; see also below) and nucleus accumbens (Fig. $4 E$ ).

In the brainstem, relatively strong glypican hybridization was seen to the red nucleus (Fig. $4 C$ ), locus coeruleus (Fig. $4 F, G$ ), and several cranial nerve nuclei, including the motor nuclei of the 5 th $(4 F, G), 7$ th $(4 H)$, and 12 th $(4 I)$ nerves. Hybridization was also seen to the oculomotor complex (Fig. $4 C$ ). In the spinal cord, relatively strong hybridization was seen to the ventral horns (not shown), and to the dorsal root ganglia (Fig. $4 J, K$ ).

Many of the brain regions where glypican hybridization was seen contain principal neurons with large, easily recognizable

\footnotetext{
Figure 4. In situ hybridization of adult rat brain with rat glypican. $A$, Coronal forebrain section probed with $4 \mathrm{X} 1$, viewed in dark field. $B$, Coronal forebrain section at the level of the anterior thalamus probed simultaneously with $4 \mathrm{X} 1$ and $4 \mathrm{P} 2$, viewed in dark field. $C$, Coronal section through the posterior thalamus and anterior midbrain, probed with $4 \mathrm{X} 1$, viewed in dark field. $D$, Coronal section at the level of that in $A$ probed with the sense (control) strand of $4 \mathrm{X} 1$, viewed in dark field. $E$, Coronal section through the anterior forebrain probed simultaneously with 4X1 and 4P2; hyperfilm image. $F$, Coronal section through the brainstem, probed with $4 \mathrm{X} 1$, viewed in dark field. $G$, A section approximately $30 \mu \mathrm{m}$ from that in $F$ stained with cresyl violet. $H$, Coronal section through the brainstem, probed with $4 \mathrm{X} 1$, viewed in dark field. $I$, Coronal section through the brainstem, probed with $4 \mathrm{X} 1$, viewed in dark field. $J$, Section through a dorsal root ganglion, probed with 4P1, viewed in dark field. Arrows point to silver grains clustered over sensory neuron cell bodies. $K$, Same section as in $J$ stained with cresyl violet. $L$, High-magnification view of the septum and lateral ventricle from a coronal section through the forebrain. $M$, Same section as in $L$ stained with cresyl violet. Asterisk in $B$ indicates supraoptic nucleus of the hypothalamus; arrow in $B$ indicates the pyramidal layer of the nucleus of the lateral olfactory tract. acc, nucleus accumbens; $b l a$, basolateral nucleus of the amygdala; $c b$, cerebellum; $c t$, cerebral cortex; $d g$, dentate gyrus; $d t$, dorsal thalamus; $e$, ependyma; $h a$, habenula; $h i$, hippocampus; $l c$, locus coeruleus; $l v$, lateral ventricle; $m e 5$, mesencephalic nucleus of the trigeminal (5th) nerve; $m g$; medial geniculate nucleus of the thalamus; $m o 5$, motor nucleus of the trigeminal (5th) nerve; $o c$, Edinger-Westphal nucleus of the oculomotor complex; $p$, piriform cortex; $r n$, red nucleus; $s$, septal area; $s c$, superior colliculus; $s n$, substantia nigra; $s t$, striatum; $s 5$, sensory nucleus of the trigeminal (5th) nerve; $t u$, olfactory tubercle; 7, nucleus of the 7th cranial nerve; 12, nucleus of the 12th cranial nerve. In the sequence reported by Karthikeyan et al. (1992), 4X1 corresponds to bases $681-843,4 \mathrm{P} 1$ corresponds to bases $1873-2440$, and 4P2 corresponds to bases $2435-2767$. Scale bars: $A-I, 500 \mu \mathrm{m} ; J$ and $K$, $200 \mu \mathrm{m} ; L$ and $M, 20 \mu \mathrm{m}$.
} 

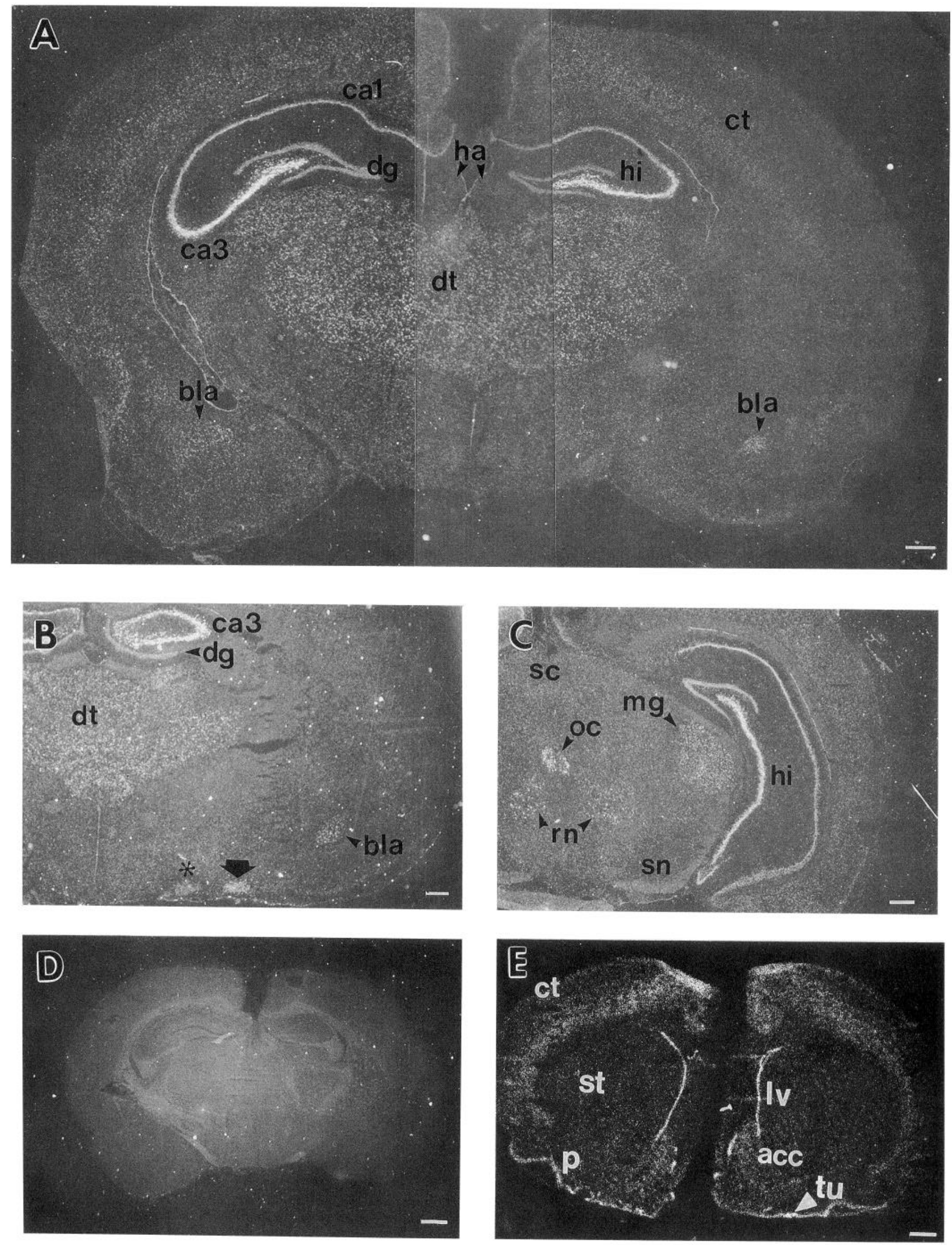

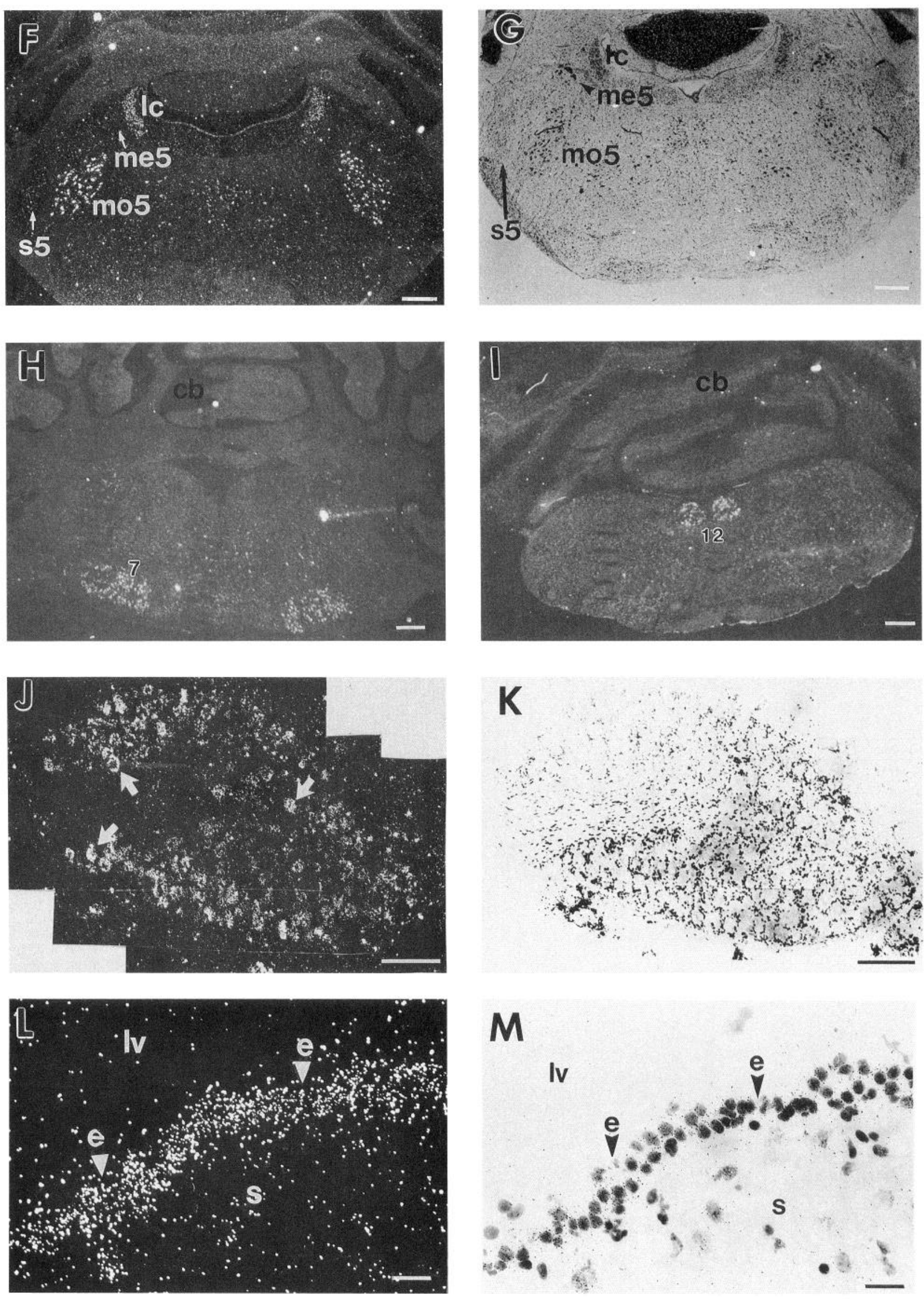
Table 2. Relative levels of glypican hybridization in the adult rat nervous system

\begin{tabular}{|c|c|c|}
\hline \multicolumn{3}{|l|}{ Forebrain } \\
\hline \multicolumn{3}{|l|}{ Cerebral neocortex } \\
\hline Layers $2 / 3,5,6$ & + & \\
\hline Layers 1,4 & - & \\
\hline \multicolumn{3}{|l|}{ Hippocampus } \\
\hline $\mathrm{CA} 1, \mathrm{CA} 2$ & ++ & \\
\hline CA3, CA4 & +++ & \\
\hline Dentate gyrus & + & \\
\hline Caudoputamen & - & \\
\hline \multicolumn{3}{|l|}{ Dorsal thalamus } \\
\hline Ventral anterior-lateral nucleus & ++ & \\
\hline Ventral posterolateral nucleus & ++ & \\
\hline Mediodorsal nucleus & ++ & \\
\hline Nucleus reuniens & ++ & \\
\hline Lateral geniculate nucleus & $+t$ & \\
\hline Medial geniculate nucleus & ++ & \\
\hline Anterodorsal & ++ & \\
\hline Anteromedial & ++ & \\
\hline Lateral dorsal & ++ & \\
\hline Anteroventral nucleus & + & ' \\
\hline \multicolumn{2}{|l|}{ Ventral thalamus } & \\
\hline Reticular nucleus & - & \\
\hline Zona incerta & - & \\
\hline \multicolumn{3}{|l|}{ Epithalamus } \\
\hline Medial habenula & - & \\
\hline Lateral habenula & - & \\
\hline \multicolumn{3}{|l|}{ Amygdaloid nuclei } \\
\hline Basolateral & ++ & \\
\hline Nucleus of the lat. olfactory tract & ++ & \\
\hline Lateral and basomedial & + & \\
\hline Anterior, medial, central, cortical & - & \\
\hline \multicolumn{3}{|l|}{ Hypothalamus } \\
\hline Supraoptic nucleus & + & \\
\hline Paraventricular nucleus & + & \\
\hline Arcuate nucleus & - & \\
\hline Piriform cortex & + & \\
\hline Olfactory tubercle & + & \\
\hline Septum & + & \\
\hline Nucleus accumbens & + & \\
\hline Endopiriform nucleus & $+1-$ & \\
\hline Ependyma & ++ & \\
\hline Large meningeal blood vessels & + & \\
\hline \multicolumn{3}{|l|}{ Brainstem } \\
\hline Superior colliculus & - & \\
\hline Inferior colliculus & - & \\
\hline Red nucleus & ++ & \\
\hline Substantia nigra & - & \\
\hline Locus coeruleus & ++ & \\
\hline \multicolumn{3}{|l|}{ Cerebellum } \\
\hline Granule cell layer & - & \\
\hline Purkinje cell layer & - & \\
\hline \multicolumn{3}{|l|}{ Cranial nerve nuclei } \\
\hline Edinger-Westphal & ++ & \\
\hline Motor V & +++ & \\
\hline Motor VII & +++ & \\
\hline Motor XII & +++ & \\
\hline Mesencephalic $V$ & $+1-$ & \\
\hline Sensory V & $+1-$ & \\
\hline
\end{tabular}

\section{Table 2. Continued}

$\begin{array}{ll}\text { Spinal cord } & \\ \text { Ventral horn motoneurons } & ++ \\ \text { Dorsal horn neurons } & +/- \\ \text { Dorsal root ganglion neurons } & ++\end{array}$

Intensity of hybridization is graded as +++ (very strong) I I (strong) I (moderate), $+/-$ (weak), or - (absent), based in part on autoradiographic exposure times. For example, structures such as fields $\mathrm{CA} 3$ and CA4 of the hippocampus were darkly exposed in $<15 \mathrm{~d}$, while structures such as the cerebral cortex were usually only detected in longer exposures ( $\geq 25 \mathrm{~d})$, or when two probes were used simultaneously during hybridization. Structures graded as - sometimes exhibited small clusters of silver grains over rare large cell bodies. Unlisted structures were not determined.

cell bodies. When sections containing these regions were examined at higher magnification, it could frequently be established that hybridization was localized to such neurons. For example, Figure $5 A$ shows glypican hybridization to cells in the nucleus of the 5 th cranial nerve. Figure $5 B$ shows that clusters of silver grains are present over large, lightly stained motoneuron cell bodies, but not over smaller, more darkly stained cell bodies (i.e., glia and small neurons). Similar results, that is, hybridization to large, lightly stained cells, were obtained in other regions of the brain, such as the thalamus and hippocampus (data not shown).

A characteristic of most of the neurons in regions that were found to express glypican mRNA is that they are projection neurons. In the cerebral neocortex, however, large numbers of local circuit neurons are also present, and in layer 4 account for a large majority of the neurons (Zilles, 1990). Interestingly, glypican hybridization was not detected in layer 4 of the cortex, but was readily detected in other cell body layers, that is, $2 / 3,5$, and 6 (Fig. $6 A, B$ ). In layer $2 / 3$, hybridization was strongest in the superficial part (Fig. $6 B$ ), and could be localized to a subpopulation of large cell bodies (Fig. $6 E, F$ ). In layers 5 and 6 , hybridization was present at all levels, and was associated with most, but not all, large cell bodies (Fig. 6C,D). Although cell body size and location alone are not sufficient to establish the projection patterns of cortical neurons, the data are at least consistent with the view that glypican is primarily expressed by projection neurons.

Many types of projection neurons throughout the brain expressed little or no glypican mRNA, however. These included most neurons of the caudoputamen (Fig. $4 E$ ), the medial and lateral habenula (Fig. 4A), the superior and inferior colliculi (Fig. $4 C$ and data not shown), the substantia nigra (Fig. $4 C$ ), and the cerebellum (Fig. $4 H, I$ ). In the latter structure, individual Purkinje cells are readily visualized, and could be clearly shown to exhibit no glypican hybridization over background (Fig. 5C,D). Although the possibility remains that levels of glypican mRNA too low to detect are present in these cells, the results emphasize the fact that levels of glypican mRNA expression throughout the brain do not merely correlate with cell body size.

In addition to being present in subsets of neurons, glypican mRNA was also found in some supporting cell (stromal) elements of the brain. For example, glypican hybridization could be seen associated with some large blood vessels, although at weaker levels than in many of the glypican-expressing neurons (data not shown). Higher but variable levels of hybridization could also be seen associated with ependymal zones (e.g., of the lateral ventricles) (Fig. $4 E, L, M$ ). 

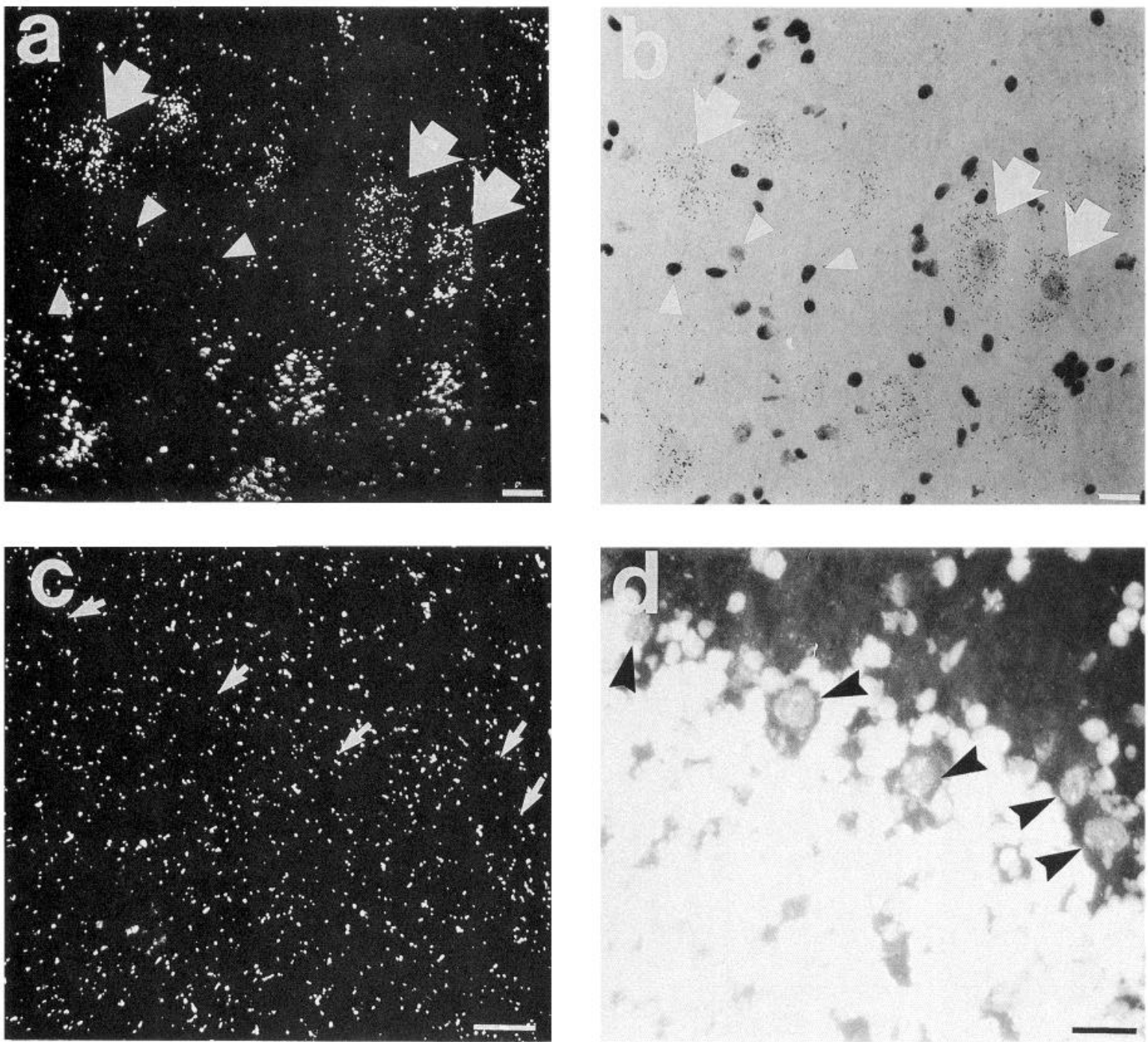

Figure 5. Neuronal expression of glypican. A, Motor nucleus of the trigeminal nerve. Arrows point to clusters of silver grains. Arrowheads point to positions of small nuclei. Dark-field view. B, Same field as in A. Arrows point to large, lightly stained nuclei under the clusters of silver grains indicated in A. Arrowheads point to small nuclei at positions indicated in $A$. C, Cerebellar cortex. Arrows point to positions of Purkinje cells. Darkfield view. $D$, Same field as in $C$. Arrowheads indicate the Purkinje cells marked in $C$. Scale bars, $20 \mu \mathrm{m}$.

\section{Discussion}

A major PG of the adult rat brain, HSPG M12, has been identified as glypican based on the following observations: (1) M12 is a GPI-anchored PG with a core protein size $(\sim 65 \mathrm{kDa})$ similar to that observed for human fibroblast glypican (David et al., 1990; Herndon and Lander, 1990), (2) peptides derived from M12 have amino acid sequences identical to those predicted from a rat glypican cDNA (this is in agreement with Karthikeyan et al., 1992, who also identified peptide sequences in a rat brain HSPG core protein that corresponded to sequences in a rat glypican cDNA), and (3) antibodies raised against a rat glypican fusion protein specifically immunoprecipitate M12 from a crude mixture of brain PGs and recognize a PG core protein that comigrates with M12 on a Western blot of heparitinase-digested brain membranes (data not shown). In addition, the expression of glypican message parallels the appearance of M12 core protein: we have found that glypican message is expressed in the adult and developing rat brain, as is M12, and that glypican mRNA can be detected by in situ hybridization in many brain regions.

\section{Neuronal expression of glypican}

The regional distribution of glypican mRNA in the adult brain, as revealed by in situ hybridization, suggests the following general features of glypican expression in the CNS.

Glypican is primarily a product of neurons. In many of the regions where glypican mRNA is expressed, neuronal cell bodies can be recognized by morphological criteria, for example, location, nuclear size, and intensity of cresyl violet staining. In such regions (e.g., hippocampus, motor nuclei, dorsal root ganglia), glypican hybridization is found directly over such cell bodies. This suggests that glial cells, which outnumber neurons in the brain, do not express glypican, although low level expression, or expression by small numbers of glia cannot be ruled out. Supporting and connective tissue elements of the brain (e.g., linings of large blood vessels, meninges, ependyma) also exhibit some glypican hybridization, although at relatively low levels compared with neuronal expression.

Glypican-expressing neurons are predominantly projection neurons. Each of the neuronal populations that expresses glypican appears to consist mainly of cells with axons that project 
A

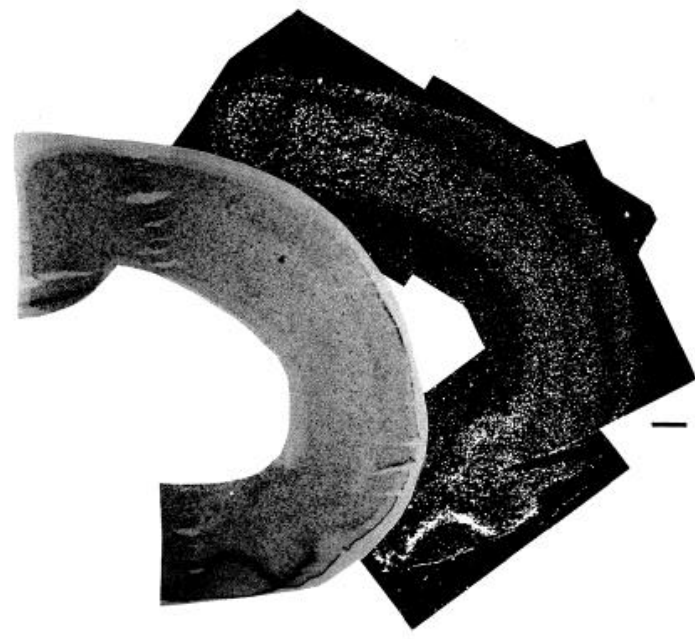

B

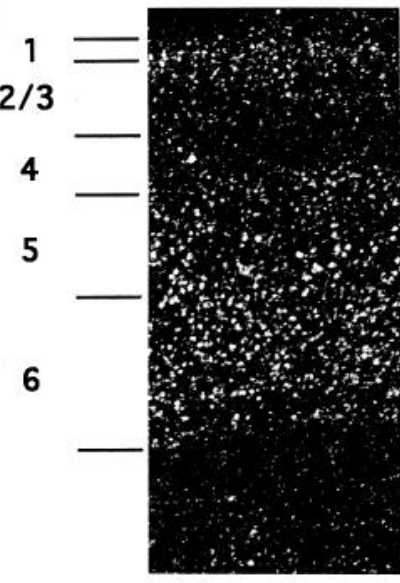

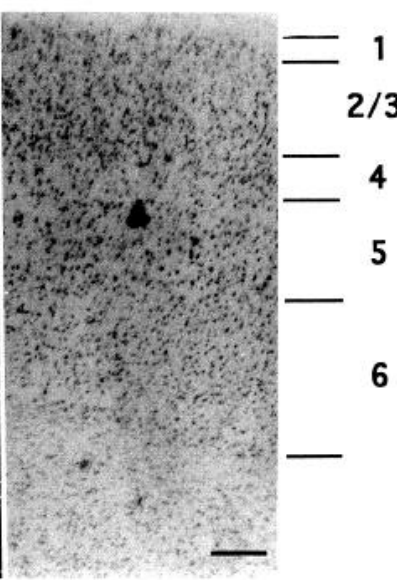

1

$2 / 3$

4

5

6
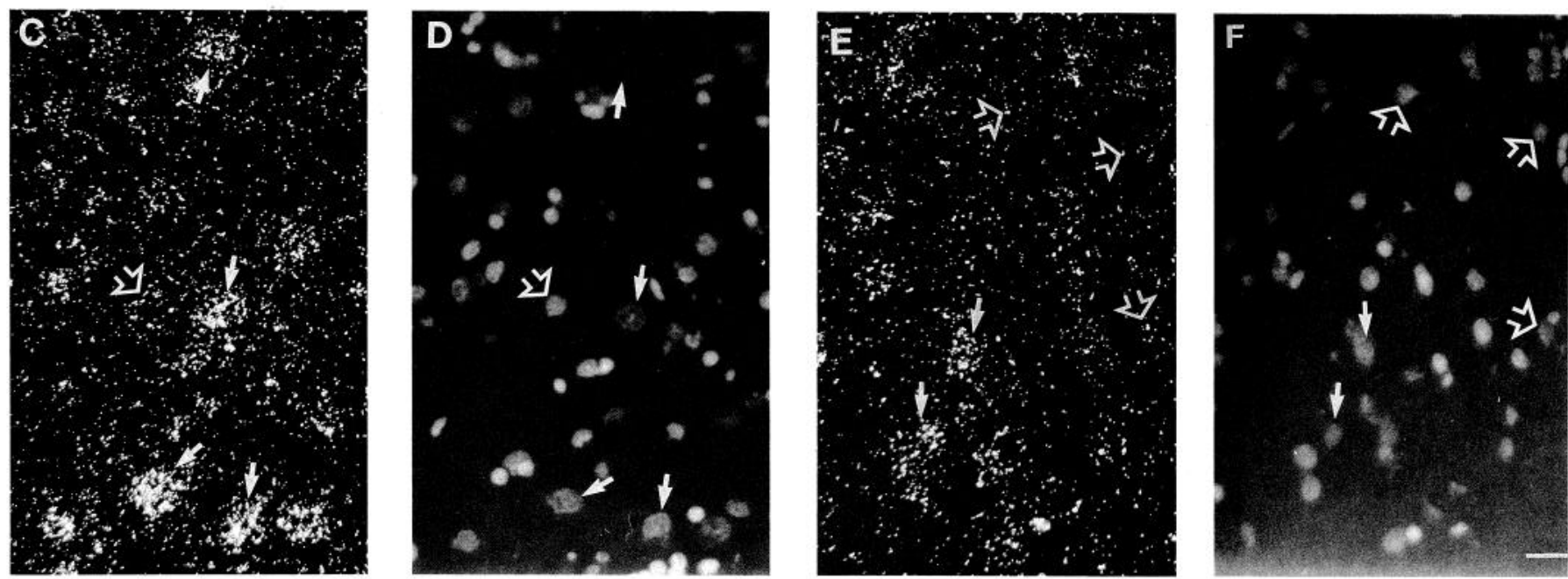

Figure 6. Glypican expression in the cerebral cortex. A: Right, Coronal section at the level of the basal ganglia stained with cresyl violet. Left, Dark-field view of coronal section $30 \mu \mathrm{m}$ from that on left hybridized simultaneously with $4 \mathrm{X} 1$ and $4 \mathrm{P} 1$. B, Magnified views of corresponding regions from sections in $A$. Lines indicate approximate divisions between cortical layers. $C$, High-magnification view of layer 5 , dark field. $D$, Same field as in $C$, stained with Hoechst 33258. E. High-magnification view of layer 2, dark field. $F$, Same field as in $E$, stained with Hoechst 33258 . Solid arrows in $C-F$ indicate clusters of silvers grains, and the cell nuclei with which they are associated; open arrows indicate large cell bodies lacking clusters of silver grains. Scale bars: $A, 500 \mu \mathrm{m} ; B, 200 \mu \mathrm{m} ; F, 20 \mu \mathrm{m}$.

to other brain regions, or, in the case of motoneurons, to the periphery. Even in the cerebral cortex, glypican expression is present in laminae with corticocortical or corticofugal connections (e.g., layers $2 / 3,5$, and 6 ), but absent from layer 4 , which consists primarily of local circuit neurons. Since projection neurons typically have long axons, relatively high levels of glypican mRNA expression might be required in some projection neurons, if it turns out that the physiological processes that involve glypican require the molecule to be present at the axonal surface. Although it remains to be determined whether glypican is, in fact, expressed on the surfaces of axons, it is known that other GPI-anchored proteins are [e.g., F3/F11 (Faivre-Sarrailh, 1992), Tag-1 (Dodd et al., 1988; Furley et al., 1990), Thy-1 (Xue et al., 1990)].

Levels of glypican mRNA expression vary substantially among different populations of neurons. Based on the autoradiographic exposure times required to detect glypican expression in different brain regions, we can estimate relative levels of glypican expression. High-level expression does not bear a simple relationship to neuronal cell body size or axon length. Indeed, some large and medium-sized projection neurons do not express detectable glypican (e.g., cerebellar Purkinje cells).

Although others have suggested that some PGs are localized to neurons that form functional or anatomical systems (Hockfield et al., 1990; Maeda et al., 1992), the types of neurons that express glypican mRNA do not correspond to any single functional or transmitter-specific subdivision of the brain. Nevertheless, limbic structures-hippocampus, amygdala, thalamus, cingulate and piriform cortex, nucleus accumbens, and septal nuclei-are relatively prominent among glypican-expressing structures. At least one other GPI-anchored protein is known to be associated with limbic system structures [LAMP (Levitt, 1984; Zacco et al., 1990; Zhukareva and Levitt, 1993)]. Also prominent among glypican-expressing neurons are neurons whose axons contribute to peripheral nerves (spinal and cranial motoneurons; dorsal root ganglion neurons). 


\section{Functional roles of glypican in the adult rat nervous system}

Although glypican is only one of many PGs in the mammalian brain, there are reasons to believe that whatever roles it plays there may be unique. In adult brain, glypican is a major HSPG, and it is the only HSPG that exhibits detergent partitioning properties indicative of an integral membrane protein (Herndon and Lander, 1990). This suggests that the bulk of the HS borne by integral membrane proteins in the adult brain may be found on glypican. Since glypican is only expressed by certain populations of neurons, this suggestion raises the interesting possibility that CNS glia and some neurons may be relatively or entirely deficient in cell-surface HS. If so, expression patterns of glypican might play an important role in restricting the sites of action of molecules that normally interact with cell-surface HS.

Among such molccules that are found in the adult brain, members of the FGF family of polypeptide growth factors are present in many locations where glypican-expressing neurons are also found. Acidic FGF, for instance, is highly expressed in spinal and cranial motoneurons, as well as neurons of the dorsal root ganglia, thalamus, septum, and red nucleus, but differs from glypican in being largely absent from the cerebral cortex and hippocampus (Elde el al., 1991; Stock et al., 1992). However, hippocampal pyramidal neurons do express basic FGF [primarily in subfield CA2 (Gómez-Pinilla et al., 1992; Woodward et al., 1992)], and FGF-5 [in subfields CA2 and CA3 (GómezPinilla and Cotman, 1992)]. Basic FGF is also found in some cranial motor nuclei (Gómez-Pinilla et al., 1992), and FGF-5 is present in skeletal muscle (Hughes et al., 1993). Although the functions of these growth factors in the adult nervous system are not known, evidence suggests that they may be involved in facilitating neuronal repair and/or neuronal survival (GómezPinilla et al., 1992; Hughes et al., 1993). Since the actions of growth factors of the FGF family apparently require the participation of the HS chains of HSPGs (Rapraeger et al., 1991; Yayon et al., 1991), glypican may play an important role in the trophic and injury responses of neurons.

Glypican could also play a role in neuronal injury responses by virtue of interactions with HS-binding extracellular matrix molecules. For example, laminin, a strongly neurite outgrowthpromoting molecule, becomes exposed in the endoneurial sheaths of peripheral nerves during nerve regeneration (Bignami et al., 1984; Longo et al., 1984); both motoneurons and primary sensory neurons express glypican, which could then be involved in the recognition of and response to endoneurial laminin. Alternatively, it is known that at least one HSPG that is released by cells strongly inhibits the neurite outgrowth effects of laminin (Muir et al., 1989); neuronal glypican might be released under some circumstances and thereby interfere with regeneration. Significantly, GPI-anchored molecules, including some GPIanchored PGs, are known to be shed by cells, presumably through the action of endogenous surface phospholipases (Ishihara et al., 1987; Carey and Evans, 1989; Low, 1989). This could account for the existence of an HSPG with biochemical properties very similar to those of glypican in the adult rat brain soluble (non-membrane-associated) fraction ("S9"; Herndon and Lander, 1990).

It is possible that glypican mediates different effects depending on its cellular source. Several heparin-binding proteins bind specifically to subfractions of heparin, suggesting that these proteins recognize aspects of GAG structure that may be found only on some HS chains (Marcum and Rosenberg, 1989; Lee and Lander, 1991; Nurcombe et al., 1993; San Antonio et al., 1993). Purification of glypican from specific neural sources, followed by binding studies with heparin-binding proteins of the brain, should indicate whether heterogeneity in the HS borne by the glypican core protein influences the kinds of molecules for which glypican, in different types of neurons, may act as a receptor.

\section{References}

Bernfield M, Kokenyesi R, Kato M, Hinkes MT, Spring J, Gallo RL, Lose EJ (1992) Biology of the syndecans: a family of transmembrane heparan sulfate proteoglycans. Annu Rev Cell Biol 8:365-393.

Bignami A, Chi NH, Dahl D (1984) Regenerating dorsal roots and the nerve entry zone: an immunofluorescence study with neurofilament and laminin antisera. Exp Neurol 85:426-436.

Carey DJ, Evans DM (1989) Membrane anchoring of heparan sulfate protcoglycans by phosphatidylinsoitol and kinctics of synthesis of peripheral and detergent-solubilized proteoglycans in Schwann cells. J Cell Biol 108:1891-1897.

Carey D, Stahl R (1990) Identification of a lipid-anchored heparan sulfate proteoglycan in Schwann cells. J Cell Biol 111:2053-2062.

Carey D, Evans D, Stahl R, Asundi V, Conner K, Garbes P, CizmeciSmith G (1992) Molecular cloning and characterization of N-syndecan, a novel transmembrane heparan sulfate proteoglycan. J Cell Biol 117:191-201.

Chomczynski P, Sacchi N (1987) Single-step method of RNA isolation by acid guanidinium thiocyanate phenol-chloroform extraction. Anal Biochem 162:156-159.

Cole GJ, Loewy A, Glaser L (1986) Neuronal cell-cell adhesion depends on interactions of N-CAM with heparin-like molecules. Nature 320:445-447.

David G, Lories V, Decock B, Marynen P, Cassiman J-J, Van den Berghe H (1990) Molecular cloning of a phosphatidylinositol-anchored membrane heparan sulfate proteoglycan from human lung fibroblasts. J Cell Biol 111:3165-3176.

Dodd J, Morton SB, Karagogeos D, Yamamoto M, Jessell TM (1988) Spatial regulation of axonal glycoprotein expression on subsets of embryonic spinal neurons. Neuron 1:105-116.

Drake SL, Klein DJ, Mickelson DJ, Oegema TR, Furcht LT, McCarthy JB (1992) Cell surface phosphatidylinositol-anchored heparan sulfate proteoglycan initiates mouse melanoma cell adhesion to a fibronectin-derived, heparin-binding synthetic peptide. J Cell Biol 117: 1331-1341.

Elde R, Cao Y, Cintra A, Brelje TC, Pelto-Huikko M, Junttila T, Fuxe K, Pettersson RF, Hokfelt T (1991) Prominent expression of acidic fibroblast growth factor in motor and sensory neurons. Neuron 7:349364.

Faivre-Sarrailh C, Gennarini G, Goridis C, Rougon G (1992) F3/F11 cell surface molecule expression in the developing mouse cerebellum is polarized at synaptic sites and with granule cells. J Neurosci 12: 257-267.

Fujita SC, Tada Y, Murakami F, Hayashi M, Matsumura M (1989) Glycosaminoglycan-related epitopes surrounding different subsets of mammalian central nervous systems. Neurosci Res 7:117-130.

Furley AJ, Morton SB, Manalo D, Karagogeos D, Dodd J, Jessell TM (1990) The axonal glycoprotein TAG-1 is an immunoglobulin superfamily member with neurite outgrowth-promoting activity. Cell 61:157-170.

Gómez-Pinilla F, Cotman CW (1992) FGF-5 mRN $\Lambda$ distribution in the rat brain: an in situ hybridization study. Soc Neurosci Abstr 18: 953.

Gómez-Pinilla F, Lee JW-K, Cotman CW (1992) Basic FGF in adult rat brain: cellular distribution and response to entorhinal lesion and fimbria-fornix transection. J Neurosci 12:345-355.

Gordon H, Lupa M, Bowen D, Hall Z (1993) A muscle cell variant defective in glycosaminoglycan biosynthesis forms nerve-induced but not spontaneous clusters of the acetylcholine receptor and the $43 \mathrm{kDa}$ protein. J Neurosci 13:586-595.

Herndon ME, Lander AD (1990) A diverse set of developmentally regulated proteoglycans is expressed in the rat central nervous system. Neuron 4:949-961.

Herndon ME, Stipp CS, Lander AD (1991) Interactions between neu- 
ronal membrane heparan sulfate protenglycans and proteins of the extracellular matrix. J Cell Biol 115:126a.

Hockfield S, Kalb RG, Zaremba S, Fryer H (1990) Expression of neural proteoglycans correlates with the acquisition of mature neuronal properties in the mammalian brain. Cold Spring Harbor Symp Quant Biol 50:505-514.

Hughes RA, Sendtner M, Goldfarb M, Lindholm D, Thoenen H (1993) Evidence that fibroblast growth factor 5 is a major muscle-derived survival factor for cultured spinal motoneurons. Neuron 10:369-377.

Ishihara M, Fedarko NS, Conrad HE (1987) Involvement of phosphatidylinositol and insulin in the coordinate regulation of proteoheparan sulfate metabolism and hepatocyte growth. J Biol Chem 262: $4708-4716$.

Iwata M, Carlson SS (1993) A large chondroitin sulfate proteoglycan has the characteristics of a general extracellular matrix component of adult brain. J Neurosci 13:195-207.

Jackson RL, Busch SJ, Cardin AC (1991) Glycosaminoglycans: Molecular properties, protein interactions, and role in physiological processes. Physiol Rev 71:481-539.

Kan M, Wang F, Xu J, Crabb JW, Hou J, McKeehan WL (1993) An essential heparin-binding domain in the fibroblast growth factor receptor kinase. Science 259:1918-1921.

Karthikeyan L, Maurel P, Rauch U, Margolis RK, Margolis RU (1992) Cloning of a major heparan sulfate proteoglycan from brain and identification as the rat form of glypican. Biochem Biophys Res Commun 188:395-401.

Klinger MM, Margolis RU, Margolis RK (1985) Isolation and characterization of the heparan sulfate proteoglycans of brain. J Biol.Chem 260:4082-4090.

Laemmli U (1970) Cleavage of structural proteins during the assembly of the head of bacteriophage T4. Nature 227:680-685.

Lander AD, Calof AL (1993) Extracellular matrix in the developing nervous system. In: Molecular genetics of nervous system tumors (Levine AJ, Schmidek HH, eds), pp 341-355. New York: Wiley.

Lee MK, Lander AD (1991) Analysis of affinity and structural selectivity in the binding of proteins to glycosaminoglycans: development of a sensitive electrophoretic approach. Proc Natl Acad Sci USA 88: $2768-2772$.

Levine JM, Card JP (1987) Light and electron microscopic localization of a cell surface antigen (NG2) in the rat cerebellum: association with smooth protoplasmic astrocytes. J Neurosci 7:2711-2720.

Levitt P (1984) A monoclonal antibody to limbic system neurons. Science 223:299-301.

Litwack ED, Stipp CS, Lander, AD (1992) Glypican, a proteoglycan, is regionally expressed in the developing rat brain. Soc Neurosci Abstr $18: 1327$

Longo FM, Hayman EG, Davis GE, Ruoslahti E, Engvall E, Manthorpe M, Varon S (1984) Neurite-promoting factors and extracellular matrix components accumulating in vivo within nerve regenerating chambers. Brain Res 309:105-117.

Low MG (1989) The glycosyl-phosphatidylinositol anchor of membrane proteins. Biochim Biophys Acta 988:427-454.

Maeda N, Matsui F, Oohira A (1992) A chondroitin sulfate proteoglycan that is developmentally regulated in the cerebellar mossy fiber system. Dev Biol 151:564-574.

Marcum JA, Rosenberg RD (1989) Role of endothelial cell surface heparin-like polysaccharides. In: Heparin and related polysaccharides (Ofosu FA, Danishefsky I, Hirsh J, eds), pp 81-94. New York: New York Academy of Science.

Margolis RU, Margolis RK, Chang LB, Preti C (1975a) Glycosaminoglycans of brain during development. Biochemistry 14:85-88.

Margolis RU, Margolis RK, Preti C, Lai D (1975b) Distribution and metabolism of glycoproteins in subcellular fractions of brain. Biochemistry 14:4797-4804.

Muir D, Engvall E, Varon S, Manthorpe M (1989) Schwannoma cellderived inhibitor of the neurite-promoting activity of laminin. J Cell Biol 109:2353-2362.

Nishiyama A, Dahlin KJ, Prince JT, Johnstone SR, Stallcup WB (1991) The primary structure of NG2, a novel membrane-spanning proteoglycan. J Cell Biol 114:359-371.

Nurcombe V, Ford MD, Wildschut IA, Bartlett PF (1993) Developmental regulation of neural response to FGF-1 and FGF-2 by heparan sulfate proteoglycan. Science 260:103-106.
Paxinos G, Watson C (1986) The rat brain in stereotaxic coordinates. Orlando, FL: Academic.

Perides G, Rahemtulla F, Lane WS, Asher, RA, Bignami A (1992) Isolation of a large aggregating proteoglycan from human brain. J Biol Chem 267:23883-23887.

Rapraeger AC, Krufka A, Olwin BB (1991) Requirement of heparan sulfate for bFGF-mediated fibroblast growth and myoblast differentiation. Science 252:1705-1708.

Rauch U, Karthikeyan L, Maurel P, Margolis RU, Margolis RK (1992) Cloning and primary structure of neurocan, a developmentally regulated, aggregating chondroitin sulfate proteoglycan of brain. J Biol Chem 267:19536-19547.

Reyes AA, Akeson R, Brezina L, Cole GJ (1990) Structural requirements for neural cell adhesion molecule-heparin interaction. Cell Regul 1:567-576.

San Antonio JD, Slover J, Lawler J, Karnovsky MJ, Lander AD (1993) Specificity in the interactions of extracellular matrix proteins with subpopulations of the glycosaminoglycan heparin. Biochemistry 32 : $4746-4755$

Schaffner W, Weissman C (1973) A rapid, sensitive, and specific method for the determination of protein in dilute solution. Anal Biochem 56:502-514.

Simmons D, Arriza J, Swanson L (1989) A complete protocol for in situ hybridization of messenger RNAs in brain and other tissues with radiolabelled single-stranded RNA probes. J Histotechnol 12:169_ 181.

Stallcup WB, Beasley L, Levine J (1983) Cell-surface molecules that characterize different stages in the development of cerebellar interneurons. Cold Spring Harbor Symp Quant Biol 48:761-774.

Stipp CS, Litwack ED, Lander AD (1994) Cerebroglycan: an integral membrane heparan sulfate proteoglycan that is unique to the developing nervous system and expressed specifically during neuronal differentiation. J Cell Biol 124:149-160.

Stock A, Kuzis K, Woodward WR, Nishi R, Eckenstein FP (1992) Localization of acidic fibroblast growth factor in specific subcortical neuronal populations. J Neurosci 12:4688-4700.

Swanson LW (1992) Brain maps: structure of the rat brain. Amsterdam: Elsevier.

Tempst P, Link AJ, Riviere LR, Fleming M, Elicone C (1990) Internal sequence analysis of proteins separated on polvacrylamide gels at the submicrogram level: improved methods, applications and gene cloning strategies. Electrophoresis 11:537-553.

Watanabe E, Fujita SC, Murakami F, Hayashi M, Matsumura M (1989) A monoclonal antibody identifies a novel epitope surrounding a subpopulation of the mammalian central nervous system. Neuroscience 29:645-657.

Woodward WR, Nishi R, Meshul CK, Williams TE, Coulombe M, Eckenstein FP (1992) Nuclear and cytoplasmic localization of basic fibroblast growth factor in astrocytes and CA2 hippocampal neurons. J Neurosci 12:142-152.

Xue GP, Calvert RA, Morris RJ (1990) Expression of the neuronal surface glycoprotein Thy-1 is under post-transcriptional control, and is spatially regulated, in the developing olfactory nervous system. Development 109:851-864.

Yanagishita M, McQuillan DJ (1989) Two forms of plasma membrane-intercalated heparan sulfate proteoglycan in rat ovarian granulosa cells. J Biol Chem 264:17551-17558.

Yayon A, Klagsbrun M, Esko JD, Leder P, Ornitz DM (1991) Cell surface, heparin-like molecules are required for binding of basic fibroblast growth factor to its high affinity receptor. Cell 64:841-848.

Zacco A, Cooper V, Chantler PD, Fisher-Hyland S, Horton HL, Levitt $P$ (1990) Isolation, biochemical characterization and ultrastructural analysis of the limbic system-associated membrane protein (LAMP), a protein expressed by neurons comprising functional neural circuits. J Neurosci 10:73-90.

Zhukareva V, Levitt P (1993) LAMP: a novel GPI-linked protein involved in cell-to-substratum adhesion by specific neuronal populations. Soc Neurosci Abstr 19:1291.

Zilles K (1990) Anatomy of the neocortex: cytoarchitecture and myeloarchitecture. In: The cerebral cortex of the rat (Kolb B, Tees RC, eds), pp 77-112. Cambridge, MA: MIT Press. 